\title{
The Epidemiology of Chronic Suppurative Lung Disease and Bronchiectasis in Children and Adolescents
}

\author{
Gabrielle B. McCallum* and Michael J. Binks \\ Child Health Division, Menzies School of Health Research, Charles Darwin University, Darwin, NT, Australia
}

In the modern era, the global burden of childhood chronic suppurative lung disease (CSLD) remains poorly captured by the literature. What is clear, however, is that CSLD is essentially a disease of poverty. Disadvantaged children from indigenous and low- and middle-income populations had a substantially higher burden of CSLD, generally infectious in etiology and of a more severe nature, than children in high-income countries. A universal issue was the delay in diagnosis and the inconsistent reporting of clinical features. Importantly, infection-related CSLD is largely preventable. A considerable research and clinical effort is needed to identify modifiable risk factors and socioeconomic determinants of CSLD and provide robust evidence to guide optimal prevention and management strategies. The purpose of this review was to update the international literature on the epidemiology, etiology, and clinical features of pediatric CSLD. University of Naples Federico II, Italy

Reviewed by: Kostas N. Priftis,

National and Kapodistrian University

of Athens, Greece

Thomas Kovesi,

Children's Hospital of Eastern

Ontario, Canada

*Correspondence:

Gabrielle B. McCallum

gabrielle.mccallum@menzies.edu.au

Specialty section: This article was submitted to Pediatric Pulmonology, a section of the journal

Frontiers in Pediatrics

Received: 25 November 2016 Accepted: 01 February 2017 Published: 20 February 2017

Citation:

McCallum GB and Binks MJ (2017)

The Epidemiology of Chronic

Suppurative Lung Disease and

Bronchiectasis in Children and

Adolescents.

Front. Pediatr. 5:27.

doi: 10.3389/fped.2017.00027
Keywords: chronic suppurative lung disease, bronchiectasis, children, epidemiology, etiology

\section{INTRODUCTION}

Bronchiectasis, a chronic progressive disease of the airways, remains one of the most neglected diseases in respiratory health (1). It is characterized by abnormal dilatation of the bronchi caused by protracted inflammation (2) and by chronic productive or wet cough (3). A definitive diagnosis of bronchiectasis requires a chest high resolution computer tomography (cHRCT) (4), with cases otherwise referred to as having chronic suppurative lung disease (CSLD) (5). Bronchiectasis or CSLD (from hereafter combined and referred to CSLD) has multiple etiologies and are often associated with underlying conditions (e.g., congenital malformation, cystic fibrosis, or immune deficiency) $(6,7)$. However, recurrent acute lower respiratory infections (ALRI) during early childhood, a crucial time for lung growth and development, are arguably the common etiology for CSLD, particularly among socially disadvantaged children $(8,9)$.

Globally, the prevalence of CSLD in high-income countries over the last 50 years has declined with the introduction of antibiotics, immunizations, improved hygiene, nutrition, and access to medical care (10-16). However, a substantial burden of CSLD persists among socially disadvantaged populations of high-income countries (e.g., Alaskan, Australian, Canadian, Maori, and Pacific Islander children) $(8,16-20)$ with the extent of pediatric CSLD in low- and middle-income countries largely

Abbreviations: ALRI, acute lower respiratory infection, cHRCT, chest high resolution computed tomography scan, CSLD, chronic suppurative lung disease, FTT, failure to thrive, NT, Northern Territory, NZ, New Zealand, Qld, Queensland, PCD, primary ciliary dyskinesia, UAE, United Arab Emirates, UK, United Kingdom, USA, United States of America, YK, Yukon-Kuskokwim. 
unknown. In recent years, there has been a growing awareness of CSLD related to the increased use of CHRCT diagnostics and emerging research into the etiology (6), microbiology, immunology (21), and clinical management (22), yet, robust epidemiological data remain sparse. Our understanding of the complex interplay between the host, pathogens, and the environment is largely superficial, and there have been few clinical intervention trials among children and adolescents. Here, we provide an update on the epidemiology, etiology, and clinical features of pediatric CSLD not associated with cystic fibrosis.

\section{GLOBAL INCIDENCE OF CSLD}

\section{Historical}

French physician Rene Laennec first described CSLD in the early nineteenth century (23), with the first surgery (24) and imaging (25) performed around 100 years later. In the 1930s, Roles described the poor prognosis of CSLD patients at the time and highlighted the importance of early diagnosis and the potential of lobectomy for enhanced survival (26). The benefit of surgery over medical management was unclear in several subsequent studies (27-30), though a surgical case series of CSLD conducted decades later was convincing, particularly for children (13). With the introduction of broad spectrum antibiotics in the 1950s, significant reductions in CSLD incidence were reported. In the United Kingdom (UK) between 1952 and 1960 (12), CSLD admissions fell fivefold from 23.8 to 4.9 per 1,000 total admissions. Similar findings were reported elsewhere in the UK (10) and in the United States of America (USA) (11). Childhood CSLD became confined to disadvantaged populations of high-income countries, earning it the label of an "orphan disease" (14). Alaskan native children $<16$ years of age appeared vulnerable with a conservatively estimated case prevalence of $41 / 100,000$ population over the decade 1956-1966, largely in the Yukon-Kuskokwim (YK) Delta and with one-third of cases associated with tuberculosis infection (16). In the 1960s, the prevalence of CSLD among Scottish children ( $<10$ years of age) was $10.6 / 100,000$ (27), and in the early 1970s, a substantial burden of CSLD was reported among indigenous children living in Central Australia (31). In this study, 83 indigenous children with CSLD were identified $(60 \%<2$ years of age) from an estimated population of around 1,000 , despite near complete eradication of tuberculosis, measles, and pertussis, previously considered to be key etiological pathogens (31). In one of the few African studies, 70/1,150 patients consecutively admitted to the University Hospital in Nigeria with respiratory or cardiovascular disease between 1975 and 1979 were diagnosed with CSLD, of which 10 (14\%) were children (32).

In the following section, we review the population incidence of pediatric CSLD in the modern era (1980-2016), when immunization and antibiotic interventions control many of the major etiological pathogens of the past, including tuberculosis, pertussis, measles, and pneumococcus.

\section{Modern Era: 1980-2016}

We performed a systematic literature review of the PubMed library followed by a bibliography search within all relevant articles. The PubMed search terms: (CSLD OR bronchiectasis) AND (pediatric OR child OR children OR infant) AND (epidemiology) yielded 351 articles, which was reduced to 243 when confined to non-cystic fibrosis-related bronchiectasis articles published since 1990 and performed after 1980, human research, and non-review articles written in English. From these, 13 relevant studies reported CSLD rates: either directly (incidence rate) or indirectly (included a bronchiectasis disease numerator, an estimate of the population denominator, and an observation period). In one New Zealand (NZ) study, age-specific data could not be accurately extracted or obtained from the authors and were, therefore, excluded (33). A government report capturing similar national NZ CSLD data was included in its place (34).

In our defined modern era (1980-2016), the burden of childhood CSLD remains difficult to characterize. In the 1980-1990s, wheezing and persistent cough were often considered clinical features of asthma and not related to CSLD. Thus, due to lack of robust evidence, misclassification was likely and management (e.g., antibiotics) possibly suboptimal. Peer reviewed published burden data were available from only nine countries, diagnostic criteria varied, population denominators were often approximate, and incidence/prevalence data were inconsistently reported. Further, hospital-based studies utilizing International Classification of Diseases coding to identify CSLD (ICD8 518, ICD9 J494, and ICD10 J47) were common. ICD coding does not provide radiological information (though several studies confirmed cHRCT diagnosis via medical records or subsequently performed cHRCT) nor distinguish between primary and repeat admissions (exacerbations), which must be ascertained by diagnosis in conjunction with date of presentation. While rare in most high-income countries, in some settings (e.g., Australian indigenous children) as many as 1 in 136 children have a new case of CSLD detected annually (8). Despite limitations in data accuracy, the trends toward higher rates of CSLD among socially disadvantaged populations were clear though perhaps partially attributed to enhanced surveillance. The collated global epidemiology data are summarized in Table 1.

\section{High-Income Countries}

In most affluent European populations, pediatric CSLD was relatively uncommon with average annual rates ranging from $0.2 / 100,000$ in the UK (37) to $2.3 / 100,000$ in Ireland (38), however, in the equally affluent, yet non-European United Arab Emirates (UAE; 13.3/100,000) (36) and largely non-European NZ $(15.0 / 100,000)(34)$, CSLD was more common. The indigenous Arabic children in the UAE children were predominantly from a wealthy social demographic with almost universal immunization coverage, therefore, the surprisingly high rates may be related to an inherited predisposition or to moderate levels of educational attainment. In NZ, the high national rate is a reflection of the high proportion of less affluent Maori and Pacific Islander people ( $\sim 40 \%)$ for which there is a well-established susceptibility to respiratory infection $(19,43,44)$. In this particular report by Simpson (34), CSLD cases were not reported by ethnicity. As clarified in the next section, the annual rate was much lower $(1.5 / 100,000)$ for NZ people of European heritage $(18,20)$. 
TABLE 1 | Burden of CSLD in children.

\begin{tabular}{|c|c|c|c|c|c|c|c|c|c|c|c|c|c|c|c|}
\hline Reference & $\begin{array}{l}\text { Pub. } \\
\text { year }\end{array}$ & Country & Region & Population & Era & $\begin{array}{c}\text { Time } \\
\text { (years) }\end{array}$ & $\begin{array}{l}\text { Male: } \\
\text { female }\end{array}$ & $\begin{array}{c}\text { Age } \\
\text { (years) }\end{array}$ & Data source & $\begin{array}{c}\text { Given or } \\
\text { extrapolated } \\
\text { BE cases }(n)\end{array}$ & $\begin{array}{l}\text { Chest high } \\
\text { resolution } \\
\text { computer } \\
\text { tomography } \\
\text { (n) }\end{array}$ & $\begin{array}{c}\text { Median } \\
\text { age at } \\
\text { diagnosis } \\
\text { (years) }\end{array}$ & $\begin{array}{l}\text { Given or rate } \\
\text { extrapolated } \\
\text { population } \\
\text { denominator } \\
\text { (n) }\end{array}$ & $\begin{array}{l}\text { Alternative }^{\mathrm{b}} \\
\text { population } \\
\text { denominator } \\
\text { estimate (n) }\end{array}$ & $\begin{array}{c}\text { Given or } \\
\text { extrapolated' } \\
\text { average } \\
\text { annual } \\
\text { incidence }\end{array}$ \\
\hline \multicolumn{16}{|c|}{ Affluent countries } \\
\hline $\begin{array}{l}\text { Saynajakangas } \\
\text { et al. (35) }\end{array}$ & 1998 & Finland & National & Non-specific & $\begin{array}{l}1983- \\
1992\end{array}$ & 10 & $31: 16$ & $<14$ & $\begin{array}{l}\text { Hospital admissions } \\
\text { (ICD8 518; ICD9 494) }\end{array}$ & 47 & na & na & $959,184^{\mathrm{a}}$ & $\begin{array}{l}944,253^{\circ} \\
(1983- \\
\text { 1992avg) }\end{array}$ & 0.5 \\
\hline $\begin{array}{l}\text { Dawson and } \\
\text { Bakalinova (36) }\end{array}$ & 1997 & UAE & Al Ain & Arabic & $\begin{array}{l}1994- \\
1995\end{array}$ & 1 & na & $1-13$ & Pediatric hospital clinic & 12 & na & na & 90,000 & $\mathrm{nr}$ & $13.3^{i}$ \\
\hline $\begin{array}{l}\text { Laverty et al. } \\
\text { (37) }\end{array}$ & 2008 & UK & $\begin{array}{l}\text { All } \\
\text { countries }\end{array}$ & Non-specific & $\begin{array}{l}2006- \\
2007\end{array}$ & 1 & na & $<16$ & Electronic registry & 23 & na & na & na & $\begin{array}{c}11,644,416^{c} \\
(2006)\end{array}$ & $0.20^{i}$ \\
\hline Zaid et al. (38) & 2010 & $\begin{array}{l}\text { Republic } \\
\text { of } \\
\text { Ireland }\end{array}$ & National & Non-specific & 2006 & 1 & na & $<18^{9}$ & $\begin{array}{l}\text { Pediatrician } \\
\text { surveillance }\end{array}$ & $24^{\mathrm{h}}$ & 24 & na & na & $\begin{array}{c}1,040,623^{\circ} \\
(2006)\end{array}$ & 2.3 \\
\hline $\begin{array}{l}\text { Simpson et al. } \\
\text { (34) }\end{array}$ & 2014 & NZ & National & Non-specific & $\begin{array}{l}2009- \\
2013\end{array}$ & 5 & na & $<15$ & $\begin{array}{l}\text { Hospital admissions } \\
\text { (ICD10 J47) }\end{array}$ & 681 & na & na & 908,000 & $\begin{array}{c}1,000,160^{\circ} \\
(2013)\end{array}$ & 15.0 \\
\hline \multicolumn{16}{|c|}{ Disadvantaged populations } \\
\hline Flynn (19) & 1994 & Fiji & Suva & Native Fijian & $\begin{array}{c}1985- \\
1989\end{array}$ & 4 & na & $5-14$ & $\begin{array}{l}\text { Hospital admissions } \\
\text { (ICD9 494) }\end{array}$ & 25 & na & na & $89,285^{a}$ & $\begin{array}{l}78,960^{d} \\
(1994)\end{array}$ & $7.0^{\circ}$ \\
\hline $\begin{array}{l}\text { Singleton et al. } \\
\text { (16) }\end{array}$ & 2000 & USA & $\begin{array}{l}\text { Alaska } \\
\text { (YK } \\
\text { Delta) }\end{array}$ & $\begin{array}{l}\text { Alaskan } \\
\text { natives }\end{array}$ & $\begin{array}{c}1980- \\
1990\end{array}$ & 10 & na & $<14^{9}$ & $\begin{array}{l}\text { Statewide registry and } \\
\text { hospitalizations }\end{array}$ & $\sim 91^{\mathrm{h}}$ & $28^{+}$ & na & na & $6,500^{\circ}(1990)$ & $\sim 140^{i}$ \\
\hline Edwards (18) & 2003 & $N Z$ & Auckland & $\begin{array}{l}\text { TOTAL } \\
\text { Pacific Island } \\
\text { Maori } \\
\text { Europeans } \\
\text { Other }\end{array}$ & $\begin{array}{l}1998- \\
2000\end{array}$ & 3 & $36: 24$ & $1-17$ & Hospital admissions & $\begin{array}{c}60 \\
33 \\
15 \\
8 \\
4\end{array}$ & 60 & 8.0 & 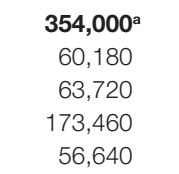 & $\begin{array}{c}307,600^{f} \\
57,000 \\
50,600 \\
167,000 \\
33,000 \text { (2001) }\end{array}$ & $\begin{array}{r}5.7^{j} \\
18.3 \\
7.9 \\
1.5 \\
2.4\end{array}$ \\
\hline Chang et al. (8) & 2003 & Australia & Central & Indigenous & $\begin{array}{l}2000- \\
2002\end{array}$ & 2 & $31: 34$ & $\leq 15$ & $\begin{array}{l}\text { Hospital admissions } \\
\text { (ICD10 J47) + medical } \\
\text { record review }\end{array}$ & 65 & 59 & 5.4 & $4,422^{\mathrm{a}}$ & $\mathrm{nr}$ & $735.0^{i}$ \\
\hline Twiss et al. (20) & 2005 & $N Z$ & National & $\begin{array}{l}\text { TOTAL } \\
\text { Pacific Island } \\
\text { Maori } \\
\text { European } \\
\text { Other }\end{array}$ & $\begin{array}{c}2001- \\
2002\end{array}$ & 2 & $28: 37$ & $\leq 15$ & $\begin{array}{l}\text { Pediatrician } \\
\text { surveillance }\end{array}$ & $\begin{array}{l}63 \\
32 \\
19 \\
18 \\
3\end{array}$ & 63 & 5.2 & 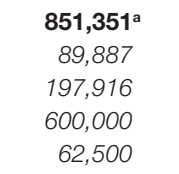 & $\begin{array}{c}877,200^{f} \\
100,000 \\
216,100 \\
652,600 \\
69,000 \text { (2001) }\end{array}$ & $\begin{array}{r}3.7 \\
17.8 \\
4.8 \\
1.5 \\
2.4\end{array}$ \\
\hline $\begin{array}{l}\text { O'Grady et al. } \\
\text { (39) }\end{array}$ & 2010 & Australia & NT & Indigenous & $\begin{array}{l}1999- \\
2004\end{array}$ & 5 & $7: 3$ & $<1$ & $\begin{array}{l}\text { Hospital admissions } \\
\text { (ICD10 J47) }\end{array}$ & 10 & na & 0.7 & 9,295 & $\mathrm{nr}$ & 118 \\
\hline
\end{tabular}


TABLE 1 | Continued

Reference

Pub. Country Region Population Era Time Male: Age Data source
year

(years) female (years)

\section{Given or \\ extrapolated ${ }^{\text {h }}$ \\ BE cases ( $n$ ) \\ Chest high \\ tomography \\ Median \\ age at \\ liagnosis \\ (years)}

(n)

\begin{tabular}{|c|c|c|c|c|c|c|c|c|c|c|c|c|c|c|c|}
\hline $\begin{array}{l}\text { Das and } \\
\text { Kovesi (17) }\end{array}$ & 2014 & Canada & $\begin{array}{l}\text { Qikiqtani, } \\
\text { Nunavut }\end{array}$ & Indigenous & $\begin{array}{c}1998- \\
2011\end{array}$ & 13 & na & $<17$ & Medical record review & 17 & 17 & 5.6 & $8,415^{a}$ & $\mathrm{nr}$ & $15.5^{i}$ \\
\hline Janu et al. (40) & 2014 & Australia & $\begin{array}{l}\text { Central } \\
\text { Qld }\end{array}$ & Indigenous & $\begin{array}{l}2007- \\
2011\end{array}$ & 5 & $4: 3$ & $<2$ & $\begin{array}{l}\text { Hospital admissions } \\
\text { (ICD10 J47) + medical } \\
\text { record review }\end{array}$ & 7 & 7 & 0.5 & $341^{a}$ & $\mathrm{nr}$ & 410 \\
\hline
\end{tabular}

Incidence standardized to an annual average per 100,000 children. Repeat bronchiectasis episodes were excluded from hospital data where possible in an attempt to focus on the index cases. Most studies reported a study observation period rather than actual person-time of observation censored at the bronchiectasis event. Censoring of these rare events in large populations would have had little effect on incidence. Given population denominators were included where possible, otherwise arate extrapolated population denominators were calculated (from numerator and rate).

${ }^{b}$ Alternative population denominators were sourced where necessary and to reaffirm rate estimated population denominators.

"World Population Prospects: the 2015 Revision. United Nations, Department of Economic and Social Affairs, Population Division. http://populationpyramid.net (accessed 2/11/2016).

${ }^{d}$ Fiji census data, 1986. http://www.statsfiji.gov.fi/statistics (accessed 2/11/2016).

eStatus of Alaskan Natives Report (41) and Alaska Native Health Status Report (42).

'Statistics New Zealand. http://nzdotstat.stats. govt.nz (accessed 7/11/2016).

${ }^{a}$ Estimated age range based on a smaller bronchiectasis study sub-popultion than that which the rate calculation was based on.

${ }^{n}$ Extrapolated numerator calculated from the given or estimated denominator and the given rate.

'Extrapolated average annual incidence calculated from the numerator, given or estimated denominator, and the study observation period.

'Extrapolated average annual incidence rate in this case was per 100,000 children born between 1980 and 1990 and followed until 1998.

na, not available; nr, not relevant.

, data estimated from a graph and unable to be confirmed by the authors.

Bold indicates the population denominator matched to the incidence calculations.

Italics highlight sub-category data that are not mutually exclusive (i. e, sums to greater than the total). 


\section{Socially Disadvantaged Populations of High-Income Countries}

The highest reported pediatric CSLD rates occur among socially disadvantaged indigenous populations of the Pacific Islands (19), NZ (18, 20), Australia (8, 39, 40), Alaska (16), and Canada (17). In the Pacific, Native Fijian children (5-14 years of age) had over 20 -fold more CSLD hospital admissions (7.0 versus $\sim 0.3 / 100,000)$ than their Indo-Fijian counterparts between 1985 and 1989 (19). Two NZ studies spanning 1998-2002, one examining national CSLD cases reported by pediatricians (20) and the other CSLD hospital admissions in Auckland (43), demonstrated the disproportionate average annual incidence among Maori $(4.8-7.9 / 100,000)$ and Pacific Islander $(17.8-18.3 / 100,000)$ compared to European children $(1.5 / 100,000)$. This disparity is directly related to child poverty. In NZ, substantially more Maori and Pacific Islander families live in poor (28-34\%), overcrowded (25-50\%) households with high unemployment rates (15\%) compared to European families (16, 5, and 5\%, respectively) (34). Similarly, in Australia and Alaska, CSLD is largely confined to indigenous children.

In the early 2000s, the average annual incidence of cHRCT confirmed bronchiectasis among indigenous children living in Central Australia was high at 735/100,000 (8). Almost all children (95\%) had pneumonia at an early age (median 6 months) and nearly two-thirds had concurrent chronic suppurative otitis media (8). Two further hospital-based studies have investigated CSLD among Australian indigenous children. The first study, a historical cohort examining the entire indigenous population of Australia's Northern Territory (NT) (both Central and Northern Australia from 1999 to 2004) showed an average CSLD incidence of 118/100,000 child-years in the first 12 months of life (39). One in five of these infants were also hospitalized with an ALRI. The early burden of respiratory illness is of particular concern in this region. The second study, a retrospective chart review conducted during 2007-2011 at the Mount Isa Base Hospital in Queensland (Qld), demonstrated an average annual incidence of 410/100,000 in children $<2$ years of age (40).

Alaskan Natives are also historically at high risk of CSLD. In a conglomeration of CSLD data from the YK Delta region (collated from a state-wide registry, historical and current patients of YK Delta Regional Hospital, or Alaska Native Medical Center), the average annual incidence of CSLD among children born between 1980 and 1990 (the review defined modern era) was 140/100,000 (16); equivalent to the incidence reported among the same population born in the 1940s (16). For a similar population, the Inuit children of Nunavut, Canada, the average annual incidence (1998-2011) of pediatric cHRCT confirmed bronchiectasis ascertained via health record reviews was lower but also substantial at $15.5 / 100,000(17)$.

Nationally in NZ (20), and among indigenous children of Australia (8), Alaska (16), and Canada (17), CSLD was diagnosed at around 5 years of age. In Auckland though, the age was slightly older at 8 years (18) and under 2 years of age for Australian indigenous infants $(39,40)$. Common to disadvantaged populations of high-income countries, was low socioeconomic status, inadequate and overcrowded housing, complex environmental and social issues, limited access to health care, frequent exposure to camp or cooking fires, high smoking rates, and almost a universal history of early infant pneumonia and/or recurrent ALRIs $(8,16-20,39,40)$. In affluent countries, CSLD is more frequently associated with non-infectious etiology (see "Etiology").

Published pediatric CSLD data (etiological, management, diagnostic, etc.) are widespread. Countries including Turkey (45-48), Saudi Arabia (49), Taiwan (50), Malaysia (51), Tunisia (52), Italy $(53,54)$, and England (55) have published excellent research (etiological, management, diagnostic, etc.), however, population-incidence could not be accurately elucidated or was not the focus of these research articles. We did not identify any incidence data among low- to middle-income countries.

\section{CSLD-RELATED MORTALITY}

There are limited data on CSLD mortality in the pediatric population. More deaths occur in adults. In Central Australia, a hospital record review showed that $34.2 \%$ (41/120) of indigenous adults diagnosed with CSLD 2001-2007 died during that same period. Most had a history of pneumonia, nearly half were diagnosed in childhood and the median age of death was 42.5 years (56). A study in England and Wales showed that only $0.2 \%(12 / 5,745)$ of total CSLD deaths recorded between 2001 and 2007 occurred among children aged $<14$ years (57). Whereas, a NZ audit of an electronic CSLD database (1991-2006), found that 7\% (6/91) of children diagnosed with CSLD (median age 7.3 years) died during follow-up (median follow-up 6.3 years) (58). A more recent study in India identified 80 children (mean age 9.6 years) with CSLD via medical record reviews. Among 62 children who were prospectively followed for 1 year, 5 (11\%) died. To avoid premature death from CSLD in both children and adults, it is vital to intervene as early as possible.

\section{ETIOLOGY AND CLINICAL MANIFESTATIONS OF PEDIATRIC CSLD}

A systematic literature review of the PubMed library using the search terms: (CSLD OR bronchiectasis) AND (pediatric OR child OR children OR infant) and restricted by time (post 1990), type (non-review), language (English only), and availability, yielded 1,163 articles. Further screening to exclude cystic-fibrosis, HIV related, surgical, small ( $<10$ CSLD cases), overlapping, or biased CSLD populations refined the list to 28 articles (Table 2). From these publications, 26 contributed etiology (Table 3 ) and 27 clinical manifestation data (Table 4).

\section{Demographics}

The 26 studies of pediatric CSLD encompassed 2,103 children from 15 countries around the world; 13 high-income (including studies within disadvantaged sub-populations) and 13 low- and middle-income countries (Table 2). The age of symptom onset varied significantly among the studies (range $0-16$ years) but was consistently present many years prior to a diagnosis of CSLD [Table 2; mean/median differences ranging from 0.8 to 7 years (Table 2)]. Some of the earliest reported symptoms were among 
TABLE 2 | Demographics of CSLD from pediatric studies.

\begin{tabular}{|c|c|c|c|c|c|c|c|}
\hline Reference & Country & Region & Era & $N$ & M:F & $\begin{array}{l}\text { Age of onset of first respiratory } \\
\text { symptoms in years, median } \\
\text { (range) }\end{array}$ & $\begin{array}{l}\text { Age at diagnosis of } \\
\text { bronchiectasis in years, } \\
\text { median (range) }\end{array}$ \\
\hline \multicolumn{8}{|l|}{ High-income countries } \\
\hline Nikolaizik and Warner (59) & UK & London & 1994 & 41 & na & na & na \\
\hline Li et al. (60) & UK & London & 1986-2002 & 136 & $65: 71$ & na & na \\
\hline Kapur et al. (61) & Australia & Qld & 1992-2009 & 113 & $64: 49$ & na & 5.3 (range 2.7-7.9) \\
\hline Eastham et al. (55) & UK & Newcastle & 1996-2002 & 93 & $62: 31$ & $1.1(0-16)$ & $7.2(1.6-18.8)$ \\
\hline Zaid et al. (38) & Ireland & Dublin & 1996-2006 & 92 & $42 / 50$ & $3.9(1-12)$ & $6.4(1.5-13)$ \\
\hline Santamaria et al. (54) & Italy & Naples & 2001-05 & 105 & $50: 55$ & $0.5(0.08-8.5)$ & $7(0-14.4)$ \\
\hline \multicolumn{8}{|c|}{ Socially disadvantaged populations of high-income countries } \\
\hline Singleton et al. (16) & Alaska & Alaska (YK delta) & 1998 & 46 & na & $0.4(0-4.8)$ & $4.8(1-15)$ \\
\hline Edwards et al. (18) & $\mathrm{NZ}$ & Auckland & 1998-2000 & 60 & $36: 24$ & $1(0-14)$ & 8 (na) \\
\hline Chang et al. (8) & Australia & Central & 2000-02 & 59 & 29:30 & $0.5(0-10)$ & $5.4(0.7-15)$ \\
\hline Twiss et al. (20) & $\mathrm{NZ}$ & National & 2001-02 & 65 & 28:37 & $2.3(0-14)$ & $5.2(0.5-15)$ \\
\hline \multirow[t]{3}{*}{ Singleton et al. (9) } & Australia & NT, SA, Qld & $2004-10$ & 97 & $55: 39$ & $0.31(0-3.9)$ & na \\
\hline & USA & Alaska (YK delta) & $2004-10$ & 41 & $22: 19$ & $0.2(0-0.8)$ & na \\
\hline & $\mathrm{NZ}$ & Auckland & $2008-10$ & 42 & $25: 17$ & $0.5(0.1-4.2)$ & na \\
\hline Munro et al. (58) & $\mathrm{NZ}$ & National & 2011 & 91 & 49:50 & na & $7.3(0.9-16)$ \\
\hline Das and Kovesi (17) & Canada & Qikiqtani, Nunavut & 2015 & 17 & na & na & $5.7(1.6-15.6)$ \\
\hline \multicolumn{8}{|c|}{ Low- and middle-income countries } \\
\hline Karadag et al. (47) & Turkey & na & 1987-2001 & 111 & $56: 55$ & $2.5 \pm 2.7^{b}$ & $7.4 \pm 3.7^{b}$ \\
\hline Karakoc et al. (45) & Turkey & Southern & 1993-99 & 23 & $13: 10$ & na & $6.2 \pm 3.6^{b}$ \\
\hline Lai et al. (50) & Taiwan & Northern & $1991-2001$ & 29 & $12: 17$ & na & na \\
\hline Bouyahia et al. (52) & Tunisia & Tunis & 1994-2006 & 41 & na & $\sim 3.1(\mathrm{na})^{\mathrm{b}}$ & $5.8(0.5-14)$ \\
\hline Banjar (49) & Saudi Arabia & Riyadh & 1993-2005 & 151 & $75: 76$ & $2.3 \pm 2.2^{b}$ & $7.3 \pm 4.1^{b}$ \\
\hline Koh et al. (62) & Korea & Seoul & 1995-96 & 25 & $14 / 11$ & na & na \\
\hline Kim et al. (63) & Korea & Seoul & 1999-2008 & 92 & $47 / 45$ & na & $7.6(0.2-18)$ \\
\hline Dogru et al. (46) & Turkey & Ankara & na & 204 & $105: 99$ & $2.3 \pm 2.2^{b}$ & 8 (na) \\
\hline Babayigit et al. (48) & Turkey & Izmar & 2003-08 & 66 & $44 / 22$ & na & na \\
\hline Nathan et al. (51) & Malaysia & Kuala Lumpur & $2004-12$ & 60 & $43 / 17$ & $0.5(0-8)$ & $1.3(0.2-11)$ \\
\hline Kumar et al. (64) & India & New Dehli & $2006-13$ & 80 & $50 / 30$ & na & $9.6(2-15)$ \\
\hline Gokdemir et al. (65) & Turkey & Istanbul & $2011-12$ & 47 & $21 / 22$ & $3.4 \pm 3.3$ & na \\
\hline Bahali et al. (66) & Turkey & Istanbul & 2013 & 76 & $32 / 44$ & $5.1 \pm 4.6$ & na \\
\hline
\end{tabular}

Adapted from Kapur et al. (67) and Brower et al. (6) and additional studies found (as able).

aUnable to access full article.

${ }^{b}$ mean $\pm S D$.

na, not available or not described.

, estimated from provided data.

indigenous infants from Australia (0.3years) (8), and Alaska (0.2 years) ( 9 ), and New Zealand ( 0.5 years) emphasizing the early origins of CSLD in high-risk children. Interestingly, Malaysian (low and middle income) and Italian (high income) children had a similar age of symptom onset ( 0.5 years). Thus, early symptom identification is essential to preventing CSLD progressing and long-term decline in lung function (68-70).

As with studies reporting incidence (several of which overlap), the demographic, etiological, and clinical data varied in their nature relating to differences from study design, study era (e.g., clinical reporting) and the age at diagnosis of children involved (e.g., unable to perform lung function $<4$ years).

\section{Etiology}

Chronic suppurative lung disease is the end result of chronic airway inflammation that is driven by persistent infection (2). As such, the natural history of CSLD depends largely on the susceptibility to both acute and chronic infection (71). Historically, congenital malformations, cystic fibrosis, immune deficiency, and aspiration are common antecedents (5), although a primary cause is not always identified. Further, measles, tuberculosis, and pertussis $(27,72)$, once the most common causes of CSLD may be less important today in the wake of advances (5) in vaccinations, antibiotics, and access to health care (67). Reviews of CSLD etiology from pediatric cohorts have been published in 2011 (67) and 2014 (6). Using a systematic search, we further updated the etiology literature, which remains similar as previous reviews and is briefly summarized below (Table 3) (17, 38, 48, 51, 58, 61, 63-66).

Less than half of the CSLD reported in high-income countries (4-35\%) $(38,54,55,59-61,73)$ and low- and middle-income countries $(10-40 \%)(45-52,62,63)$ was identified as postinfectious; yet, a history of early infant pneumonia and/or recurrent ALRIs was almost universally common to indigenous children of Alaska (93\%) (16), Australia (90\%) (8), and Canada (94\%) (17). A separate case-control study in Central Australia also found a strong relationship between severe recurrent pneumonia in early childhood and development of CSLD (74). In the South Korean study by Kim et al., 89\% (17/19) children with infectious etiology 
TABLE 3 | Etiology of CSLD from pediatric studies.

\begin{tabular}{|c|c|c|c|c|c|c|c|}
\hline & Postinfection (\%) & $\begin{array}{c}\text { Immune deficiency } \\
(\%)\end{array}$ & $\begin{array}{l}\text { Primary ciliary } \\
\text { dyskinesia (\%) }\end{array}$ & $\begin{array}{c}\text { Congenital } \\
\text { malformations (\%) }\end{array}$ & Aspiration (\%) & Idiopathic (\%) & Other (\%) \\
\hline \multicolumn{8}{|l|}{ High-income countries } \\
\hline Nikolaizik and Warner (59) & 32 & 27 & 17 & 15 & 5 & 2 & 2 \\
\hline Li et al. (60) & 4 & 34 & 15 & 4 & 18 & 26 & 0 \\
\hline Eastham et al. $(55)^{\mathrm{b}}$ & 35 & 26 & 1 & 9 & 5 & 18 & 14 \\
\hline Zaid et al. (38) & 17 & 22 & 9 & 1 & 22 & 32 & 3 \\
\hline Kapur et al. (61) & 12 & 12 & 2 & na & 11 & 55 & 8 \\
\hline Santamaria et al. (54) & 7 & 10 & 24 & na & 4 & 55 & 0 \\
\hline \multicolumn{8}{|c|}{ Socially disadvantaged populations of high-income countries } \\
\hline Singleton et al. (16) & 93 & na & na & na & 4 & na & na \\
\hline Edwards et al. (18) & 25 & 12 & 0 & na & 10 & 50 & 3 \\
\hline Chang et al. (8) & 90 & 3 & 0 & 1 & 5 & 0 & 2 \\
\hline Twiss et al. (20) & 22 & 6 & 0 & 0 & 6 & 54 & 11 \\
\hline Munro et al. (58) & 23 & 9 & na & na & na & 45 & 23 \\
\hline Das and Kovesi (17) & 94 & 0 & 0 & na & 6 & na & 12 \\
\hline \multicolumn{8}{|c|}{ Low- and middle-income countries } \\
\hline Karadag et al. (47) & 30 & 15 & 6 & 3 & 4 & 38 & 4 \\
\hline Karakoc et al. (45) & 35 & 17 & 13 & na & na & na & $34^{c}$ \\
\hline Lai et al. (50) & 28 & 10 & 3 & 3 & 7 & 31 & 18 \\
\hline Bouyahia et al. (52) ${ }^{a}$ & 10 & 10 & 10 & na & na & 48 & $22^{c}$ \\
\hline Banjar (49) & na & 18 & 11 & 7 & 10 & 40 & 14 \\
\hline Koh et al. (62) & 24 & na & 24 & na & na & 52 & 0 \\
\hline Kim et al. (63) & 21 & 9 & 4 & na & na & 14 & $65^{d}$ \\
\hline Dogru et al. (46) & 16 & 5 & 12 & na & 3 & 49 & 15 \\
\hline Babayigit et al. (48) & 21 & 8 & 6 & 3 & 9 & 33 & 17 \\
\hline Nathan et al. (51) & 40 & 7 & na & 10 & na & 18 & na \\
\hline Kumar et al. (64) & 24 & 6 & 15 & 4 & 3 & 36 & na \\
\hline Gokdemir et al. (65) & 19 & 19 & 26 & na & 2 & 33 & na \\
\hline Bahali et al. (66) & 16 & 4 & 20 & na & na & 53 & 8 \\
\hline
\end{tabular}

Adapted from Kapur et al. (67) and Brower et al. (6).

aUnable to access full article.

na, not available or not described.

Etiology is described where available.

${ }^{b}$ Multiple etiologies occurred in some children, therefore, the sum is $>100 \%$.

Includes cystic fibrosis

${ }^{d}$ Bronchiolitis obliterans (33\%) and interstitial lung disease (17\%) were common.

had tuberculosis (63). Taken together, these findings reinforce the notion that the high burden of CSLD among indigenous children is related to substandard living conditions and is essentially preventable.

In affluent European populations where CSLD is less common, immune deficiency was identified in a larger proportion of cases $(10-34 \%)(38,54,55,59-61,73)$ than among indigenous populations $(0-12 \%)(8,16-18,20,58)$ and in low- and middle-income countries (4-19\%) (45-52, 62-66), where acute respiratory infections are endemic and CSLD is more common. Other main differences highlighted in Table 3 were the higher proportion of children with primary ciliary dyskinesia (PCD) in high- and lowand middle-income countries (1-24 and 3-26\%, respectively) $(38,45-52,54,55,59-63,73)$ compared to indigenous children where PCD was not reported $(8,16-18,20,58)$. Despite improved diagnostics and case management globally, the proportion of CSLD cases with unknown etiology was relatively consistent (0-55\%; Table 3) apart from in London (2\%) (59) and among indigenous children $(0 \%)$ where most cases were accounted for $(8,16)$. It is likely that previous infections play more of a role in the development of CSLD than is currently known. This is of particular concern in low- and middle-income countries where children with recurrent respiratory infections often have limited access to medical care. Even more concerning is that the actual burden of CSLD in these countries is largely unknown.

\section{CLINICAL FEATURES AND OUTCOMES}

In this update of the literature surrounding clinical features of CSLD, importantly, we have included the largest prospective international multicenter study for $\operatorname{CSLD}$ in children $(9,75)$. The most comprehensive clinical data in this section are recorded among indigenous populations and low- and middle-income countries (summarized in Table 4).

Clinical features of CSLD differ depending on the extent of the disease. In CSLD, recurrent wet or productive cough is probably the earliest and most important symptom to recognize and investigate, although it should be noted that young children do not readily expectorate (3). Despite the importance of cough in respiratory health, this was only specifically reported in 59\% 
TABLE 4 | Clinical features reported in children with CSLD.

\begin{tabular}{|c|c|c|c|c|c|c|c|c|c|c|}
\hline & $\begin{array}{c}\text { Cough } \\
(\%)\end{array}$ & $\begin{array}{c}\text { Wheeze } \\
(\%)\end{array}$ & $\begin{array}{c}\text { Chest } \\
\text { deformity } \\
(\%)\end{array}$ & $\begin{array}{c}\text { Clubbing } \\
(\%)\end{array}$ & $\begin{array}{c}\text { Hemoptysis } \\
(\%)\end{array}$ & $\begin{array}{c}\text { Failure } \\
\text { to thrive } \\
\text { (FTT) } \\
\text { (\%) }\end{array}$ & $\begin{array}{c}\text { FEV1\% } \\
\text { predicted, } \\
\text { median (range) }\end{array}$ & $\begin{array}{l}\text { FVC\% predicted, } \\
\text { median (range) }\end{array}$ & $\begin{array}{l}\text { Chest } \\
\text { pain } \\
(\%)\end{array}$ & $\begin{array}{c}\text { Dyspnea } \\
(\%)\end{array}$ \\
\hline \multicolumn{11}{|l|}{ High-income countries } \\
\hline Nikolaizik and Warner (59) & na & na & na & na & na & na & na & na & na & na \\
\hline Li et al. (60) & 35 & 10 & na & na & na & 4 & $71(15-133)$ & 77 (14-22) & na & na \\
\hline Kapur et al. (61) & na & na & na & na & na & na & na & na & na & na \\
\hline Eastham et al. (55) & na & na & na & na & na & na & na & na & na & na \\
\hline Zaid et al. (38) & na & na & na & na & na & na & na & na & na & na \\
\hline Santamaria et al. (54) & na & na & na & na & na & na & $95(26-144)$ & $96(30-132)$ & na & na \\
\hline \multicolumn{11}{|c|}{ Socially disadvantaged populations of high-income countries } \\
\hline Singleton et al. (16) & na & na & na & na & na & 17 & na & na & na & na \\
\hline Edwards et al. (18) & na & na & 60 & 52 & na & 8 & $69(36-110)^{b}$ & $86(33-109)^{b}$ & na & na \\
\hline Chang et al. (8) & $100^{c}$ & na & 60 & 26 & na & 73 & $66.2(38-98)$ & $70.2(40.2-110)$ & na & na \\
\hline Twiss et al. (20) & 40 & na & na & na & na & na & 77 (na) & 85 (na) & na & na \\
\hline \multirow{3}{*}{ Singleton et al. (9) } & 50 & 7 & 14 & 10 & na & 82 & na & na & na & 30 \\
\hline & 75 & 41 & 18 & 5 & na & 95 & na & na & na & 58 \\
\hline & 52 & 17 & 57 & 45 & na & 74 & na & na & na & 26 \\
\hline Munro et al. (58) & na & na & 42 & 41 & na & 15 & $66(18-116)^{b}$ & $72(17-123)^{b}$ & na & na \\
\hline Das et al. (17) & 59 & na & na & na & na & 12 & $78(63-108)$ & na & na & na \\
\hline \multicolumn{11}{|c|}{ Low- and middle-income countries } \\
\hline Karadag et al. (47) & 97 & 47 & 15 & 41 & 10 & na & $63.3(22.1)^{\mathrm{b}}$ & $67.3(23.1)^{\mathrm{b}}$ & na & 50 \\
\hline Karakoc et al. (45) & 91 & 48 & na & na & na & na & $68.45(13.70)^{b}$ & $70.34(9.56)^{b}$ & na & 57 \\
\hline Lai et al. (50) & 93 & 35 & na & 21 & 41 & na & $67.6(43.8)^{b}$ & $82.5(39.1)^{\mathrm{b}}$ & na & 10 \\
\hline Bouyahia et al. (52) & na & na & 27 & 27 & 5 & na & na & na & na & 34 \\
\hline Banjar et al. (49) & $>66$ & $>66$ & na & 33 & 5 & $>66$ & na & na & na & na \\
\hline Koh et al. (62) & 28 & 28 & na & na & na & na & $83(7)^{\mathrm{b}}$ & na & na & 28 \\
\hline Kim et al. (63) & 50 & 20 & na & 4 & 8 & na & 63 (na) & 71 (na) & 3 & 25 \\
\hline Dogru et al. (46) & 83 & na & 1 & 13 & 4 & 46 & na & na & na & 9 \\
\hline Babayigit et al. (48) & 100 & 20 & 5 & 23 & 5 & 27 & na & na & na & na \\
\hline Nathan et al. (51) & na & na & na & na & na & na & $52(32-76)$ & $58(37-76)$ & na & na \\
\hline Kumar et al. (64) & 96 & 53 & na & na & 16 & 10 & na & $\mathrm{Na}$ & 43 & na \\
\hline Gokdemir et al. (65) & na & na & na & na & na & na & $79.8(20.6)^{b}$ & $80.0(17.8)^{b}$ & na & na \\
\hline Bahali et al. (66) & na & na & na & na & na & na & $72.0(21.9)^{b}$ & $76.4(20.0)^{b}$ & na & na \\
\hline
\end{tabular}

Adapted from Kapur et al. (67).

aUnable to access full article. Signs and symptoms overlap often totaling $>100 \%$.

${ }^{b}$ Mean $\pm S D$ and/or range.

na, not available or not described; FEV , forced expiratory volume in first second; FVC, forced vital capacity

'Study inclusion specifically >4 months daily moist and/or productive cough. FIT was inconsistently defined. In the Singleton study (9), FIT was reported as $\leq 2$ SD below norm.

$(16 / 27)$ of studies, though we acknowledge in many studies, it may have been assumed or captured in other scoring algorithms. Low- and middle-income countries consisting of Turkey [7\% (47), 91\% (45), and 100\% (48)], India [96\% (64)], and Taiwan [93\% (50)] and the indigenous cohorts of Alaska [75\% (9)], Australia [100\% (8)], and NZ [52\% (9)] reported high rates of cough. Under-appreciating the importance of cough may delay diagnosis and treatment, which can lead to a decline in lung function and poorer long-term prognosis (76). Likewise, cough is an important clinical feature of CSLD exacerbations (1).

In low- to middle-income countries, the proportion of CSLD children presenting with wheeze ranged from $20 \%$ in Tunisia (48) and South Korea (63) to 66\% (49) in Saudi Arabia, though it was unclear whether all $66 \%$ of the Saudi children had wheeze as it co-reported with other symptoms. The only high-income country reporting wheeze was the UK where $10 \%$ of children were identified. Interestingly, in the multicenter study of indigenous children (9), Alaskan natives had a much higher percentage of wheezing
(41\%) than either indigenous children of Australia (7\%) or Pacific Islander and Maori children of NZ (17\%). This correlated with an earlier study that showed both Alaskan native children with (65\%) and without (37\%) CSLD had higher rates of wheeze (77). It is likely that there are different underlying susceptibilities to and clinical manifestations of CSLD across population groups, but further exploration is needed to further understand these relationships.

Inadequate nutrition (macro and micro) is another factor that can increase the risk of developing and/or worsening CSLD by compromising innate and adaptive immunity (78), which can have long-term consequences (67). As an example, sufficient vitamin $\mathrm{D}$ is known to be important for regulating immune responses to respiratory pathogens (79). Among indigenous Australian children, deficiency is associated with an increased risk of hospitalization for respiratory infection (80). A typical feature of suboptimal energy and protein intake is failure to thrive (FTT), which was reported just over one-third of studies. 
Not surprisingly, FTT was most frequent in socially disadvantaged populations; indigenous children from Australia (73-82\%) $(8,9)$, Alaska (95\%), NZ (74\%) (9), and low- and middle-income countries of Turkey (46\%) (46) and Saudi Arabia (66\%) (49).

Currently, cHRCT (the gold standard) and pulmonary function measurements are the most frequently used objective tools used to assess CSLD. Abnormal lung function over time predicts poor quality of life score (81-83). The percent predicted forced expiratory volume in 1 second $\left(\mathrm{FEV}_{1}\right)$ reported across studies varied, but was lower among children from indigenous $(8,18)$ and low- and middle-income countries $(8,18,47,62)$ than for children from high-income countries (54-61, 63-72) suggesting more severely affected lung function (Table 4).

Since the previous review by Kapur et al. (67), a further two studies $(17,63)$ reporting lobar involvement (cHRCT) were identified, making 15 studies in total $(8,16-18,20,38,45-50,54$, $55,63)$. Multi-lobar involvement was reported in all 15 studies and was most common in Taiwan (50), NZ (18), Canada (17), and in Saudi Arabia (49). The number of affected lobes varied between studies. The left lower lobe $(80 \%)$ and right lower lobe (60\%) were most commonly affected. Whether multi-lobar involvement relates to clinical severity and poorer outcomes remains uncertain.

In more advanced CSLD, clinical features include chest wall deformity, digital clubbing, hemoptysis, and dyspnea. Again, these markers were common to indigenous populations and low- and middle-income countries (Table 4). A further feature, chest pain, was reported in two studies from Seoul (3\%) (63) and India (43\%) (64). It is possible that chest pain relates to a delayed diagnosis of CSLD (median age 7.6 years in Korea and 9.6 years in India) again emphasizing the need for earlier symptom surveillance and diagnosis to improve clinical outcomes for children with CSLD. In the longer term, complications associated with CSLD extend beyond the respiratory system including cardiovascular disease an area requiring further investigation (84).

While there are limited long-term clinical data, these studies indicate that children with CSLD have different clinical manifestations across populations. These data also highlights that children from socially disadvantaged groups (e.g., indigenous populations and low- and middle-income countries) appear to have more extensive clinical features and greater propensity for poorer longterm outcomes than those from high-income countries.

\section{PREVENTION AND MANAGEMENT}

Despite the high global burden of respiratory diseases, only a small percentage of research and development funding and resources are devoted to these conditions $(71,85)$. To prevent CSLD, a multidisciplinary approach is required beginning in the antennal period continuing throughout childhood. Key strategies include immunizations, improved hygiene, nutrition, and education (that is culturally appropriate) to improve health-related outcomes for children with $\operatorname{CSLD}(9,86)$. Other fundamental factors to consider are exposure to tobacco, camp fire, biomass fuels, and other environmental air pollutants, overcrowding, housing quality, and access to running water. Evidence-based clinical guidelines have been developed in several settings to guide primary and secondary health care $(22,78,87,88)$, yet, more robust and consistent evidence from populations across the globe is essential. Other papers in this series will focus on the management of CSLD in more detail.

\section{FUTURE RESEARCH}

There is a need for more epidemiological research globally to clarify the prevalence of CSLD, in particular, for at-risk populations (e.g., indigenous and low- and middle- income countries). Importantly, there are also no long-term prospective studies in children to guide clinical care and management into adolescence and adulthood. Clinical trials across multiple countries are essential to further improve interventional and clinical management of CSLD. This can only be achieved with substantial investment and support from governments and funding bodies.

\section{CONCLUSION}

Once considered an "orphans disease" among high-income populations, this review reinforces that CSLD remains a disease of poverty, common among children from indigenous populations and low- and middle-income countries. Delayed diagnosis was common as was severe disease. Despite the fact that the burden of CSLD in these settings was primarily related to early preventable infections, this condition is neglected globally in terms of research priority and funding. To improve the respiratory health of disadvantaged children, a concerted international effort is needed to determine and understand the burden of pediatric CSLD and to provide a solid evidence base for future clinical care and management.

\section{AUTHOR CONTRIBUTIONS}

All authors listed have made substantial, direct, and intellectual contribution to the work and approved it for publication.

\section{ACKNOWLEDGMENTS}

We would like to thank Professor Anne Chang for guidance on the structure of the article. Thank you to Jennifer Wong and Erin Plumb for reviewing the manuscript.

\section{FUNDING}

This manuscript is supported by a National Health and Medical Research Council-Centre for Research Excellence in Lung Health of Aboriginal and Torres Strait Islander Children (1040830). Both authors are supported by National Health and Medical Research Council Early career Fellowship [GM (1111705) and MB (1088733)]. 


\section{REFERENCES}

1. European Respiratory Society. European Lung White Book. Sheffield: European Respiratory Society (2016).

2. King P. Pathogenesis of bronchiectasis. Paediatr Respir Rev (2011) 12:104-10. doi:10.1016/j.prrv.2010.10.011

3. Chang AB, Redding GJ, Everard ML. Chronic wet cough: protracted bronchitis, chronic suppurative lung disease and bronchiectasis. Pediatr Pulmonol (2008) 43:519-31. doi:10.1002/ppul.20821

4. Bonavita J, Naidich DP. Imaging of bronchiectasis. Clin Chest Med (2012) 33:233-48. doi:10.1016/j.ccm.2012.02.007

5. Chang AB. Bronchiectasis: so much yet to learn and to do. Paediatr Respir Rev (2011) 12:89-90. doi:10.1016/j.prrv.2011.01.001

6. Brower KS, Del Vecchio MT, Aronoff SC. The etiologies of non-CF bronchiectasis in childhood: a systematic review of 989 subjects. BMC Pediatr (2014) 14:4. doi:10.1186/s12887-014-0299-y

7. Goyal V, Grimwood K, Marchant J, Masters IB, Chang AB. Pediatric bronchiectasis: no longer an orphan disease. Pediatr Pulmonol (2016) 51:450-69. doi:10.1002/ppul.23380

8. Chang AB, Masel JP, Boyce NC, Wheaton G, Torzillo PJ. Non-CF bronchiectasis: clinical and HRCT evaluation. Pediatr Pulmonol (2003) 35:477-83. doi:10.1002/ppul.10289

9. Singleton RJ, Valery PC, Morris P, Byrnes CA, Grimwood K, Redding G, et al. Indigenous children from three countries with non-cystic fibrosis chronic suppurative lung disease/bronchiectasis. Pediatr Pulmonol (2014) 49:189-200. doi:10.1002/ppul.22763

10. Strang C. The fate of children with bronchiectasis. Ann Intern Med (1956) 44:630-56.

11. Glauser EM, Cook CD, Harris GB. Bronchiectasis: a review of 187 cases in children with follow-up pulmonary function studies in 58. Acta Paediatr Scand (1966) 165:1.

12. Field CE. Bronchiectasis. Third report on a follow-up study of medical and surgical cases from childhood. Arch Dis Child (1969) 44:551-61.

13. Sanderson JM, Kennedy MC, Johnson MF, Manley DC. Bronchiectasis: results of surgical and conservative management. A review of 393 cases. Thorax (1974) 29:407-16.

14. Barker AF, Bardana EJ Jr. Bronchiectasis: update of an orphan disease. Am Rev Respir Dis (1988) 137:969-78. doi:10.1164/ajrccm/137.4.969

15. Keistinen T, Saynajakangas O, Tuuponen T, Kivela SL. Bronchiectasis: an orphan disease with a poorly-understood prognosis. Eur Respir J (1997) 10:2784-7.

16. Singleton RJ, Morris A, Redding G, Poll J, Holck P, Martinez P, et al. Bronchiectasis in Alaska native children: causes and clinical courses. PediatrPulmonol (2000) 29:182-7.

17. Das L, Kovesi TA. Bronchiectasis in children from Qikiqtani (Baffin) Region, Nunavut, Canada. Ann Am Thorac Soc (2015) 12:96-100. doi:10.1513/ AnnalsATS.201406-257OC

18. Edwards EA, Asher MI, Byrnes CA. Paediatric bronchiectasis in the twenty-first century: experience of a tertiary children's hospital in New Zealand. J Paediatr Child Health (2003) 39:111-7.

19. Flynn MG. Hospital admission rates for asthma and pneumonia in Fijian and Indian children. J Paediatr Child Health (1994) 30:19-22.

20. Twiss J, Metcalfe R, Edwards EA, Byrnes C. New Zealand national incidence of bronchiectasis "too high" for a developed country. Arch Dis Child (2005) 90:737-40.

21. Grimwood K. Airway microbiology and host defences in paediatric non-CF bronchiectasis. Paediatr Respir Rev (2011) 12:111-8. doi:10.1016/ j.prrv.2010.10.009

22. Chang AB, Grimwood K, Maguire G, King PT, Morris PS, Torzillo PJ. Management of bronchiectasis and chronic suppurative lung disease in indigenous children and adults from rural and remote Australian communities. Med J Aust (2008) 189:386-93.

23. Roguin A. Rene Theophile Hyacinthe Laennec (1781-1826): the man behind the stethoscope. Clin Med Res (2006) 4:230-5.

24. Heidenhain L. Extensive lung resection due to festering bronchiectasis in a lower lobe. Negotiations Ger Soc Surg (1901) 30:636

25. Sicard JA, Forestier J. Iodized oil as a contrast medium in radioscopy. Bull et mem Soc med d hop de Par (1922) 46:463-9.
26. Roles FC, Todd GS. Bronchiectasis: diagnosis and prognosis in relation to treatment. Br Med J (1933) 2:639-43.

27. Clark NS. Bronchiectasis in childhood. Br Med J (1963) 1:80-8.

28. Field CE. Bronchiectasis in childhood; III. Prophylaxis, treatment and progress with a follow-up study of 202 cases of established bronchiectasis. Pediatrics (1949) 4:355-72.

29. Franklin AW. The prognosis of bronchiectasis in childhood. Arch Dis Child (1958) 33:19-23.

30. Wynn-Williams N. Observations on the treatment of bronchiectasis and its relation to prognosis. Tubercle (1957) 38:133-45.

31. Maxwell GM. Chronic chest disease in Australian aboriginal children. Arch Dis Child (1972) 47:897-901.

32. Adebonojo SA, Grillo IA, Osinowo O, Adebo OA. Suppurative diseases of the lung and pleura: a continuing challenge in developing countries. Ann Thorac Surg (1982) 33:40-7.

33. Bibby S, Milne R, Beasley R. Hospital admissions for non-cystic fibrosis bronchiectasis in New Zealand. N Z Med J (2015) 128:30-8.

34. Simpson J, Oben G, Wicken A, Adams J, Reddington A, Duncanson M. Child Poverty Monitor 2014 Technical Report. NZ Child \& Youth Epidemiology Service. Dunedin: University of Otago (2014).

35. Saynajakangas O, Keistinen T, Tuuponen T, Kivela SL. Evaluation of the incidence and age distribution of bronchiectasis from the Finnish hospital discharge register. Cent Eur J Public Health (1998) 6:235-7.

36. Dawson KP, Bakalinova D. Childhood chronic lung disease in the United Arab Emirates. Trop Doct (1997) 27:151-3.

37. Laverty A, Jaffe A, Cunningham S. Establishment of a web-based registry for rare (orphan) pediatric lung diseases in the United Kingdom: the BPOLD registry. Pediatr Pulmonol (2008) 43:451-6. doi:10.1002/ppul. 20783

38. Zaid AA, Elnazir B, Greally P. A decade of non-cystic fibrosis bronchiectasis 1996-2006. Ir Med J (2010) 103:77-9.

39. O'Grady KA, Torzillo PJ, Chang AB. Hospitalisation of Indigenous children in the Northern Territory for lower respiratory illness in the first year of life. Med J Aust (2010) 192:586-90.

40. Janu EK, Annabattula BI, Kumariah S, Zajaczkowska M, Whitehall JS, Edwards MJ, et al. Paediatric hospitalisations for lower respiratory tract infections in Mount Isa. Med J Aust (2014) 200:591-4.

41. Goldsmith S, Howe L, Angvik J, Leask L, Hill A. Status of Alaskan Natives Report. Anchorage: The Institute of Social and Economic Research (ISER) at the University of Alaska (2004).

42. Alaska Native Epidemiology Center. Alaska Native Health Status Report. Alaska Native Tribal Health Consortium (2009).

43. Edwards EA, Metcalfe R, Milne DG, Thompson J, Byrnes CA. Retrospective review of children presenting with non cystic fibrosis bronchiectasis: HRCT features and clinical relationships. Pediatr Pulmonol (2003) 36:87-93. doi:10.1002/ppul.10339

44. Williams JV, Harris PA, Tollefson SJ, Halburnt-Rush LL, Pingsterhaus JM, Edwards KM, et al. Human metapneumovirus and lower respiratory tract disease in otherwise healthy infants and children. N Engl J Med (2004) 350:443-50. doi:10.1056/NEJMoa025472

45. Karakoc GB, Yilmaz M, Altintas DU, Kendirli SG. Bronchiectasis: still a problem. Pediatr Pulmonol (2001) 32:175-8.

46. Dogru D, Nik-Ain A, Kiper N, Gocmen A, Ozcelik U, Yalcin E, et al. Bronchiectasis: the consequence of late diagnosis in chronic respiratory symptoms. J Trop Pediatr (2005) 51:362-5. doi:10.1093/tropej/fmi036

47. Karadag B, Karakoc F, Ersu R, Kut A, Bakac S, Dagli E. Non-cystic-fibrosis bronchiectasis in children: a persisting problem in developing countries. Respiration (2005) 72:233-8. doi:10.1159/000085362

48. Babayigit A, Olmez D, Uzuner N, Cakmakci H, Tuncel T, Karaman O. A neglected problem of developing countries: noncystic fibrosis bronchiectasis. Ann Thorac Med (2009) 4:21-4. doi:10.4103/1817-1737.44781

49. Banjar HH. Clinical profile of Saudi children with bronchiectasis. Indian J Pediatr (2007) 74:149-52.

50. Lai SH, Wong KS, Liao SL. Clinical analysis of bronchiectasis in Taiwanese children. Chang Gung Med J (2004) 27:122-8.

51. Nathan AM, Muthusamy A, Thavagnanam S, Hashim A, de Bruyne J. Chronic suppurative lung disease in a developing country: impact on child and parent. Pediatr Pulmonol (2014) 49:435-40. doi:10.1002/ppul.23001 
52. Bouyahia O, Essadem L, Matoussi N, Gharsallah L, Fitouri Z, Mrad Mazigh S, et al. Etiology and outcome of bronchiectasis in children: a study of 41 patients. Tunis Med (2008) 86:996-9.

53. Scala R, Aronne D, Palumbo U, Montella L, Giacobbe R, Martucci P, et al. Prevalence, age distribution and aetiology of bronchiectasis: a retrospective study on 144 symptomatic patients. Monaldi Arch Chest Dis (2000) 55:101-5.

54. Santamaria F, Montella S, Pifferi M, Ragazzo V, De Stefano S, De Paulis N, et al. A descriptive study of non-cystic fibrosis bronchiectasis in a pediatric population from central and southern Italy. Respiration (2009) 77:160-5. doi:10.1159/000137510

55. Eastham KM, Fall AJ, Mitchell L, Spencer DA. The need to redefine non-cystic fibrosis bronchiectasis in childhood. Thorax (2004) 59:324-7.

56. Einsiedel L, Fernandes L, Spelman T, Steinfort D, Gotuzzo E. Bronchiectasis is associated with human T-lymphotropic virus 1 infection in an indigenous Australian population. Clin Infect Dis (2012) 54:43-50. doi:10.1093/cid/cir766

57. Roberts HJ, Hubbard R. Trends in bronchiectasis mortality in England and Wales. Respir Med (2010) 104:981-5. doi:10.1016/j.rmed.2010.02.022

58. Munro KA, Reed PW, Joyce H, Perry D, Twiss J, Byrnes CA, et al. Do New Zealand children with non-cystic fibrosis bronchiectasis show disease progression? Pediatr Pulmonol (2011) 46:131-8. doi:10.1002/ppul.21331

59. Nikolaizik WH, Warner JO. Aetiology of chronic suppurative lung disease. Arch Dis Child (1994) 70:141-2.

60. Li AM, Sonnappa S, Lex C, Wong E, Zacharasiewicz A, Bush A, et al. Non-CF bronchiectasis: does knowing the aetiology lead to changes in management? Eur Respir J (2005) 26:8-14.

61. Kapur N, Grimwood K, Masters IB, Morris PS, Chang AB. Lower airway microbiology and cellularity in children with newly diagnosed non-CF bronchiectasis. Pediatr Pulmonol (2012) 47:300-7. doi:10.1002/ppul.21550

62. Koh YY, Lee MH, Sun YH, Sung KW, Chae JH. Effect of roxithromycin on airway responsiveness in children with bronchiectasis: a double-blind, placebo-controlled study. Eur Respir J (1997) 10:994-9.

63. Kim HY, Kwon JW, Seo J, Song YH, Kim BJ, Yu J, et al. Bronchiectasis in children: 10-year experience at a single institution. Allergy Asthma Immunol Res (2011) 3:39-45. doi:10.4168/aair.2011.3.1.39

64. Kumar A, Lodha R, Kumar P, Kabra SK. Non-cystic fibrosis bronchiectasis in children: clinical profile, etiology and outcome. Indian Pediatr (2015) 52:35-7.

65. Gokdemir Y, Hamzah A, Erdem E, Cimsit C, Ersu R, Karakoc F, et al. Quality of life in children with non-cystic-fibrosis bronchiectasis. Respiration (2014) 88(1):46-51. doi:10.1159/000360297

66. Bahali K, Gedik AH, Bilgic A, Cakir E, Ustabas Kahraman F, Keskin Osmanoglu $\mathrm{N}$, et al. The relationship between psychological symptoms, lung function and quality of life in children and adolescents with non-cystic fibrosis bronchiectasis. Gen Hosp Psychiatry (2014) 36:528-32. doi:10.1016/ j.genhosppsych.2014.05.019

67. Kapur N, Karadag B. Differences and similarities in non-cystic fibrosis bronchiectasis between developing and affluent countries. Paediatr Respir Rev (2011) 12:91-6. doi:10.1016/j.prrv.2010.10.010

68. Morgan J. Indigenous Australians and the struggle for health equality. Lancet Respir Med (2015) 3:188-9. doi:10.1016/S2213-2600(15)00045-4

69. Tennant PW, Gibson GJ, Parker L, Pearce MS. Childhood respiratory illness and lung function at ages 14 and 50 years: childhood respiratory illness and lung function. Chest (2010) 137:146-55. doi:10.1378/chest.09-0352

70. Chang AB, Grimwood K, Mulholland EK, Torzillo PJ. Working group on indigenous paediatric respiratory $\mathrm{H}$. bronchiectasis in indigenous children in remote Australian communities. Med J Aust (2002) 177:200-4.

71. Chang AB, Marsh RL, Upham JW, Hoffman LR, Smith-Vaughan H, Holt $\mathrm{D}$, et al. Toward making inroads in reducing the disparity of lung health in Australian indigenous and New Zealand Maori children. Front Pediatr (2015) 3:9. doi:10.3389/fped.2015.00009

72. Field CE. Bronchiectasis. A long-term follow-up of medical and surgical cases from childhood. Arch Dis Child (1961) 36:587-603.
73. Kapur N, Masters IB, Chang AB. Exacerbations in noncystic fibrosis bronchiectasis: clinical features and investigations. Respir Med (2009) 103:1681-7. doi:10.1016/j.rmed.2009.05.007

74. Valery PC, Torzillo PJ, Mulholland K, Boyce NC, Purdie DM, Chang AB. Hospital-based case-control study of bronchiectasis in indigenous children in Central Australia. Pediatr Infect Dis J (2004) 23:902-8.

75. Valery PC, Morris PS, Byrnes CA, Grimwood K, Torzillo PJ, Bauert PA, et al. Long-term azithromycin for Indigenous children with non-cystic-fibrosis bronchiectasis or chronic suppurative lung disease (Bronchiectasis Intervention Study): a multicentre, double-blind, randomised controlled trial. Lancet Respir Med (2013) 1:610-20. doi:10.1016/S2213-2600(13)70185-1

76. Morey MJ, Cheng AC, McCallum GB, Chang AB. Accuracy of cough reporting by carers of Indigenous children. J Paediatr Child Health (2013) 49:E199-203. doi: $10.1111 /$ jpc.12118

77. Redding G, Singleton R, Lewis T, Martinez P, Butler J, Stamey D, et al. Early radiographic and clinical features associated with bronchiectasis in children. Pediatr Pulmonol (2004) 37:297-304. doi:10.1002/ppul.10427

78. Chang AB, Bell SC, Byrnes CA, Grimwood K, Holmes PW, King PT, et al. Chronic suppurative lung disease and bronchiectasis in children and adults in Australia and New Zealand. Med J Aust (2010) 193:356-65.

79. Mora JR, Iwata M, von Andrian UH. Vitamin effects on the immune system: vitamins A and D take centre stage. Nat Rev Immunol (2008) 8:685-98. doi:10.1038/nri2378

80. Binks MJ, Smith-Vaughan HC, Marsh R, Chang AB, Andrews RM. Cord blood vitamin $\mathrm{D}$ and the risk of acute lower respiratory infection in indigenous infants in the Northern Territory. Med J Aust (2016) 204:238.

81. Stocks J, Hislop A, Sonnappa S. Early lung development: lifelong effect on respiratory health and disease. Lancet Respir Med (2013) 1:728-42. doi:10.1016/S2213-2600(13)70118-8

82. Steinfort DP, Brady S, Weisinger HS, Einsiedel L. Bronchiectasis in Central Australia: a young face to an old disease. Respir Med (2008) 102:574-8. doi:10.1016/j.rmed.2007.11.007

83. Martinez-Garcia MA, Perpina-Tordera M, Roman-Sanchez P, Soler-Cataluna JJ. Quality-of-life determinants in patients with clinically stable bronchiectasis. Chest (2005) 128:739-45. doi:10.1378/chest.128.2.739

84. Jousilahti P, Vartiainen E, Tuomilehto J, Puska P. Symptoms of chronic bronchitis and the risk of coronary disease. Lancet (1996) 348:567-72. doi:10.1016/ S0140-6736(96)02374-4

85. Viergever RF. The mismatch between the health research and development ( $R \& D$ ) that is needed and the R\&D that is undertaken: an overview of the problem, the causes, and solutions. Global Health Action (2013) 6:22450. doi:10.3402/gha.v6i0.22450

86. McCallum GB, Morris PS, Brown N, Chang AB. Culture-specific programs for children and adults from minority groups who have asthma. Cochrane Database Syst Rev (2016). (in press).

87. Chang AB, Bell SC, Torzillo PJ, King PT, Maguire GP, Byrnes CA, et al. Chronic suppurative lung disease and bronchiectasis in children and adults in Australia and New Zealand Thoracic Society of Australia and New Zealand guidelines. Med J Aust (2015) 202:130.

88. British Thoracic Society. Guideline for non-CF bronchiectasis. Thorax (2010) 65(Suppl 1):577.

Conflict of Interest Statement: The authors declare that the research was conducted in the absence of any commercial or financial relationships that could be construed as a potential conflict of interest.

Copyright (c) 2017 McCallum and Binks. This is an open-access article distributed under the terms of the Creative Commons Attribution License (CC BY). The use, distribution or reproduction in other forums is permitted, provided the original author(s) or licensor are credited and that the original publication in this journal is cited, in accordance with accepted academic practice. No use, distribution or reproduction is permitted which does not comply with these terms. 